\title{
Early Phase of Intestinal Mantle Cell Lymphoma: A Report of Two Cases Associated with Advanced Colonic Adenocarcinoma
}

\author{
Kazunori Kanehira, M.D., Raul C. Braylan, M.D., Gregory Y. Lauwers, M.D. \\ Department of Pathology and Laboratory Medicine, University of Florida College of Medicine, Gainesville, \\ Florida (KK, RCB); and James Homer Wright Pathology Laboratories, Department of Pathology, \\ Massachusetts General Hospital and Harvard Medical School, Boston, Massachusetts (GYL)
}

\begin{abstract}
Intestinal mantle cell lymphoma characteristically produces multiple polyps, a finding reported as multiple lymphomatous polyposis. The early stages of intestinal mantle cell lymphoma before polyp formation and the pattern of initial lymph node invasion, however, have not been described. We recently encountered two cases of intestinal mantle cell lymphoma in their early development found incidentally associated with advanced colonic adenocarcinoma. We present herein the clinical, histopathological, immunohistochemical, and molecular genetic features of these two cases. In one case, a single polypoid mass was found with invasion limited to mucosa and submucosa of the terminal ileum and without lymph node compromise. In the second case, there were multiple mucosal aggregates of neoplastic cells without formation of polyps. Regional lymph nodes in the latter case showed either partial or complete involvement by lymphoma. In both cases, immunohistochemistry (CD20+, CD5+, cyclin D1+, CD10-, and CD23-), and demonstration of clonal immunoglobulin heavy chain and bcl-1 gene rearrangements by PCR analysis confirmed the diagnosis of mantle cell lymphoma.
\end{abstract}

KEY WORDS: Colon carcinoma, Intestinal lymphoma, Lymphomatous polyposis, Mantle cell lymphoma.

Mod Pathol 2001;14(8):811-817

Copyright (C) 2001 by The United States and Canadian Academy of Pathology, Inc

VOL. 14, NO. 8, P. 811, 2001 Printed in the U.S.A.

Date of acceptance: April 18, 2001.

Address reprint requests to: Gregory Y. Lauwers, M.D., Department of

Pathology, Massachusetts General Hospital, 55 Fruit Street-Warren 256,

Boston, MA 02114; e-mail: glauwers@partners.org; fax: 617-726-7474.
Colonic adenocarcinoma is one of the most common human neoplasms and is the most frequently diagnosed gastrointestinal malignancy (1). Conversely, primary gastrointestinal lymphoma is a relatively uncommon neoplasm that is most frequently diagnosed in the stomach and less frequently in the colon (2). The occurrence of both adenocarcinoma and primary lymphoma in the same digestive organ is a rare event, and only a few cases have been documented (3-5).

Mantle cell lymphoma is a well-characterized hematopoietic malignancy. The translocation of the bcl-1 gene on chromosome 11 to chromosome 14, where the immunoglobulin heavy-chain gene resides, is commonly observed in this lymphoma and results in up-regulation of bcl-1 protein expression (6), and the detection of the $t(11 ; 14)$ by PCR analysis has been used to support its diagnosis (7). Mantle cell lymphoma usually affects peripheral lymph nodes and is characterized by early dissemination to spleen, bone marrow, and peripheral blood (6). Although mantle cell lymphoma presenting as a primary gastrointestinal tumor is infrequent, it has been well described in the literature $(8,9)$. It either produces multiple intestinal polyps, and the term multiple lymphomatous polyposis has been applied to these characteristic lesions, or it can present as a dominant tumor, often present in the ileocecal region (8-10). Recent series have shown that intestinal mantle cell lymphomas tend to present at advanced stages and carry a poor prognosis $(10,11)$.

In the present report, we describe the clinicopathologic features of two cases of early primary intestinal mantle cell lymphoma found incidentally in association with advanced colonic adenocarcinoma.

\section{MATERIALS AND METHODS}

\section{Histology and Immunohistochemistry}

Representative tissue samples were submitted for routine histology, fixed in $10 \%$ neutral-buffered for- 
malin, and paraffin embedded. Tissue sections were stained with hematoxylin and eosin.

Immunohistochemical staining was performed on paraffin-embedded sections. The reagents used included antibodies against CD3, CD20 (L26), CD5, and cyclin D1 (DAKO, Carpinteria, CA), CD10 and CD23 (Vector, Burlingame, CA), and Ki-67 (MIB-1) (Immunotech, Westbrook, ME). Four-micron-thick sections were sequentially deparaffinized in two changes of xylene (5 minutes each), hydrated in decreasing concentrations of ethanol, and rinsed in deionized water. Endogenous peroxidase was blocked with $3 \% \mathrm{H}_{2} \mathrm{O}_{2}$ for 4 minutes at room temperature. Sections prepared for CD3, CD20, CD5, $\mathrm{CD} 23$, and Ki-67 staining were placed in citrate buffer, pH 6 (Sigma Chemical Company, St. Louis, MO), microwaved for 10 minutes at $50 \%$ power (model: EM-1500S, Sanyo, Little Ferry, NJ), and allowed to cool for 15 minutes. Sections for CD10 and cyclin D1 staining were also microwaved for the same time, but high $\mathrm{pH}$ target retrieval solution (DAKO) was used instead. Staining was performed on a Ventana 320 immunostainer (Ventana, Tucson, AZ). A biotin-streptavidin detection system was employed, with diaminobenzidine as the chromogen (BioGenex, San Ramon, CA).

The proliferative activity was determined by counting the percentage of ki-67-immunoreactive cells. The most immunoreactive areas were selected, and a minimum of 500 cells was assessed.

\section{Molecular Genetics}

PCR analysis was performed to detect clonal rearrangements of the immunoglobulin heavy-chain gene and the $t(11 ; 14)(q 13 ; q 32)$ translocation in paraffin-embedded tissue. DNA was extracted from 5 - $\mu \mathrm{m}$-thick paraffin sections with xylene, hydrated through graded alcohols, and digested with 60 $\mu \mathrm{g} / \mathrm{mL}$ proteinase $\mathrm{K}$ (Boehringer-Mannheim, Indianapolis, IN) in Tris- $\mathrm{HCl}$ buffer ( $\mathrm{pH} 7.5)$ overnight at $55^{\circ} \mathrm{C}$.

Primers for immunoglobulin heavy-chain rearrangements $\left(\mathrm{V}_{\mathrm{H}}-\mathrm{FR} 3 \mathrm{~A}-\mathrm{J}_{\mathrm{H}}\right)$ and primers and probe for the bcl-1 major translocation cluster were as described in Trainor et al. (12) and Segal et al. (13), respectively. A 200-ng aliquot of genomic DNA was amplified in a Perkin-Elmer Cetus 9600 thermocycler (Perkin-Elmer, Norwalk, CT) with $1.25 \mathrm{U}$ of Taq polymerase (Perkin-Elmer) in a $50 \mu \mathrm{L}$ reaction volume containing $\left(\mathrm{NH}_{4}\right)_{2} \mathrm{SO}_{4}$ buffer, $\mathrm{pH} 8.8$ (12) and final concentrations of $1.5 \mathrm{mmol} / \mathrm{L} \mathrm{MgCl}_{2}, 200$ $\mu \mathrm{mol} / \mathrm{L}$ dNTP (Amersham Pharmacia Biotech, Inc., Piscataway, NJ), and $5 \mathrm{pmol}$ and $40 \mathrm{pmol}$ of primers for the bcl-1 and heavy-chain gene amplifications, respectively. Amplification consisted of 40 cycles of denaturation ( 1 minute at $94^{\circ} \mathrm{C}$ ), annealing (1.5 minute at $\left.58^{\circ} \mathrm{C}\right)$, and extension $\left(1.5\right.$ minute at $72^{\circ}$
C). PCR products of the bcl-1 translocation amplification were electrophoresed through a $1.75 \%$ agarose gel (BRL Ultrapure, Rockville, MO), transferred by vacuum onto nylon membrane, then probed with a 3' tailed dioxygenin (DIG)-labeled oligonucleotide, followed by anti-DIG-AP antibody, visualized using a BCIP/NBT colorimetric method (Boehringer-Mannheim). PCR products of the immunoglobulin heavy-chain gene amplification were electrophoresed through a $4 \%$ MetaPhor agarose gel (FMC Bioproducts, Rockland, ME) and visualized by ethidium bromide. A known mantle cell lymphoma sample and a hyperplastic tonsil were used as positive and negative controls, respectively.

\section{RESULTS}

\section{Case Histories}

Case 1 is a 54 year-old white man with a history of rectal bleeding and anemia. Physical examination was negative for palpable lymphadenopathy. A blood cell count revealed 5800 leukocytes $/ \mathrm{mm}^{3}$ (neutrophils: $66.9 \%$, lymphocytes: $20.2 \%$, monocytes: $7.8 \%$, eosinophils: $3.6 \%$, basophils: $1.5 \%$ ) and 230,000 platelets $/ \mathrm{mm}^{3}$. The hemoglobin level was $11.2 \mathrm{~g} / \mathrm{dL}$. A colonoscopy revealed a hemorrhagic mass at the hepatic flexure, and a biopsy of the lesion demonstrated adenocarcinoma. A computed tomographic scan showed a few nodules in the liver, suspicious for metastatic adenocarcinoma. Spleen was normal, and no abdominal lymphadenopathy was noted. Consequently, the patient underwent a right hemicolectomy, with liver biopsy confirming metastatic disease. After the surgical pathology report (see later in this article) a bone marrow biopsy was performed that showed no abnormalities, either by microscopy or by flow cytometry. The patient is receiving combination chemotherapy for metastatic adenocarcinoma and is well 6 months after surgery.

Case 2 is a 74-year-old male who had a 2-month history of rectal bleeding and anemia. On physical examination, no superficial palpable adenopathy was noted. A blood cell count revealed 6900 leukocytes $/ \mathrm{mm}^{3}$ (neutrophils: $79.5 \%$, lymphocytes: $9.1 \%$, monocytes: $9.6 \%$, eosinophils: $1.6 \%$, basophils: $0.2 \%$ ) and 250,000 platelets $/ \mathrm{mm}^{3}$. The hemoglobin level was $9.8 \mathrm{~g} / \mathrm{dL}$. Colonoscopy showed a rectal mass that, on biopsy, demonstrated adenocarcinoma. CT scan showed multiple slightly enlarged lymph nodes in the retrocrural and mesenteric region. Spleen and liver were unremarkable. The patient underwent a low anterior resection. After surgery (see pathology report later in this article), a bone marrow biopsy was performed that showed no morphologic evidence of involvement by malignant lymphoma. However, flow cytometric analysis 
of a bone marrow aspirate revealed minimal involvement by a clonal B-cell population coexpressing CD19 and CD5, suggesting the presence of circulating lymphoma cells. The patient has been well for 4 months after surgery and has completed external radiation therapy for local control of the rectal adenocarcinoma.

\section{Pathologic Findings}

\section{Case 1}

The resected colon showed two distinct lesions. One $8.0 \times 6.0 \times 2.0$-cm exophytic mass was identified in the ascending colon, $6.0 \mathrm{~cm}$ from the distal colonic margin. Microscopic examination of this lesion revealed a moderately differentiated adenocarcinoma invading through the muscularis propria into pericolonic fibroadipose tissue (Fig. 1). No atypical lymphocytic infiltrate was noted in this area. A separate polypoid lesion measuring $4.0 \times$ $3.0 \times 1.0 \mathrm{~cm}$ was noted in the terminal ileum. The mass had a homogenous and granular, tan cut surface and histologically was characterized by a vague nodular proliferation of lymphoid cells limited to mucosa and submucosa (Fig. 2). The atypical smallto medium-sized lymphocytes had irregular nuclei,
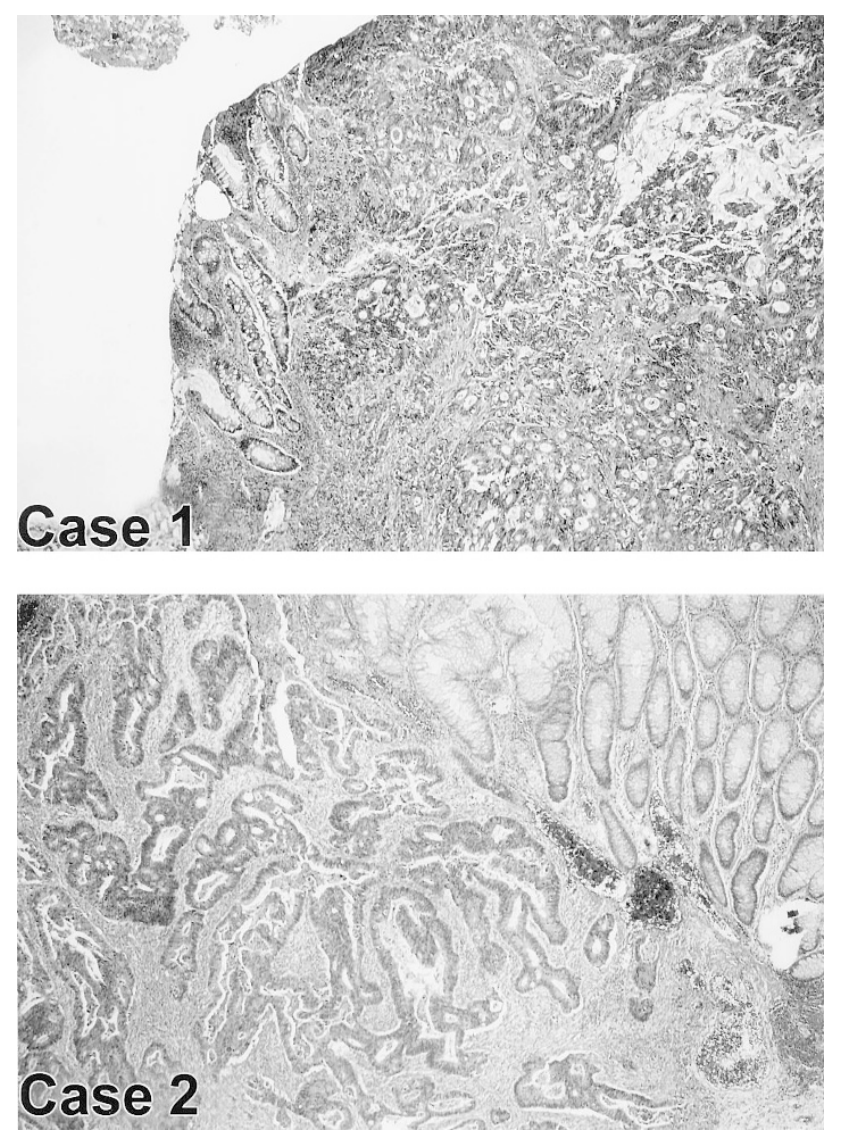

FIGURE 1. Colonic adenocarcinoma from Cases 1 and 2. Both cases represent moderately differentiated adenocarcinomas (hematoxylin and eosin staining; original magnification, $40 \times$ ). moderately coarse chromatin, inconspicuous nucleoli, and scant cytoplasm (Fig. 2). Mitoses were infrequent $(<1$ per 10 high power field). Lymphoepithelial lesions were not present, and plasmacytoid differentiation was not identified. No other polypoid lesion was observed. All regional lymph nodes were negative for metastatic adenocarcinoma or obvious lymphomatous involvement. A concurrent liver biopsy showed metastatic colonic adenocarcinoma.

\section{Case 2}

The rectum showed a large ulcerating mass that measured $3.0 \times 2.5 \mathrm{~cm}$ and extended to the muscularis propria. A large necrotic lymph node and additional pericolorectal nodes were also identified. Histologic sections showed a moderately differentiated adenocarcinoma extending through the muscularis propria into pericolonic fibroadipose tissue (Fig. 1). Surprisingly, sections of the resection margins showed multiple small lymphoid aggregates in the colonic mucosa and submucosa (Fig. 3). These aggregates, devoid of germinal centers, were comprised of small lymphocytes with slightly irregular nuclei, inconspicuous nucleoli and scant cytoplasm (Fig. 3). Lymphoepithelial lesions were not identified. In addition, a random section of grossly unremarkable colon, distant from the colonic carcinoma, revealed similar lymphoid infiltrates. The large, necrotic node showed metastatic adenocarcinoma, but nine additional small lymph nodes $(\leq 0.3 \mathrm{~cm})$ showed either partial or complete involvement by malignant lymphoma (Fig. 4).

A summary of the main pathologic and clinical findings in these two cases is presented in Table 1 .

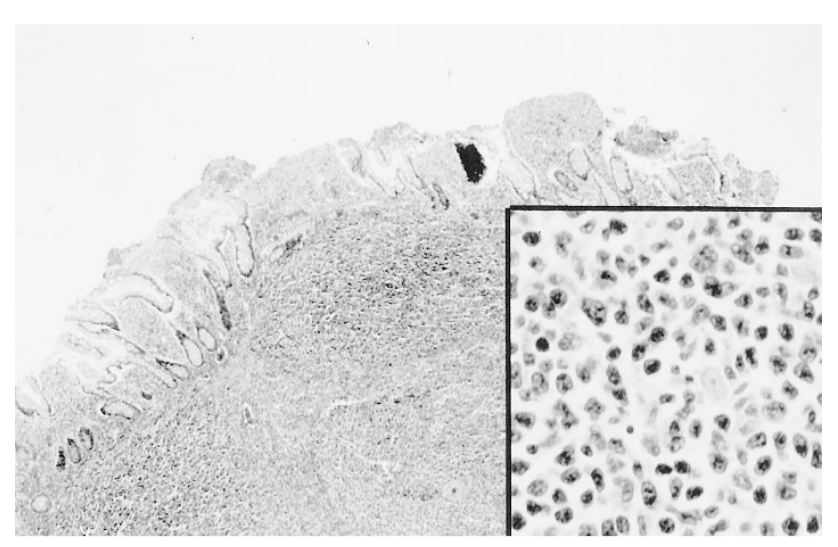

FIGURE 2. Mantle cell lymphoma from Case 1. Lymphoma cells invade massively to submucosa forming a polypoid mass. Note the vague nodular pattern of the neoplasm (hematoxylin and eosin staining; original magnification, $40 \times$ ). The tumor is composed of smallto medium-sized lymphocytes with irregular nuclei showing coarse chromatin and inconspicuous nucleoli (inset, hematoxylin and eosin staining; original magnification $600 \times$ ). 


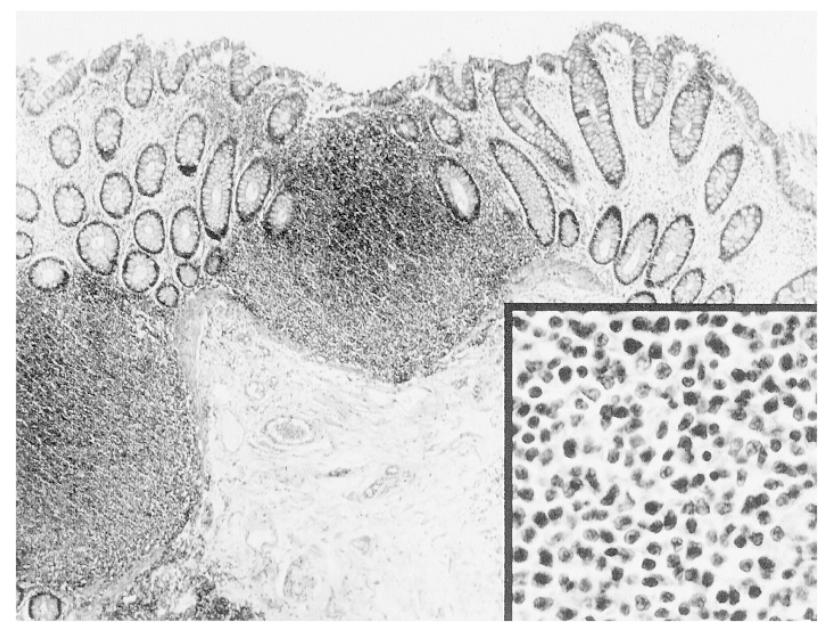

FIGURE 3. Colonic mucosa from Case 2 showing multiple lymphoid aggregates. High-power view shows monotonous proliferation of small lymphocytes (hematoxylin and eosin staining; original magnification, $40 \times$ ). The cells in this neoplasm demonstrate nuclei that are similar to those in Case 1 but with slightly less irregular nuclei (inset, hematoxylin and eosin staining; original magnification, $600 \times$ ).
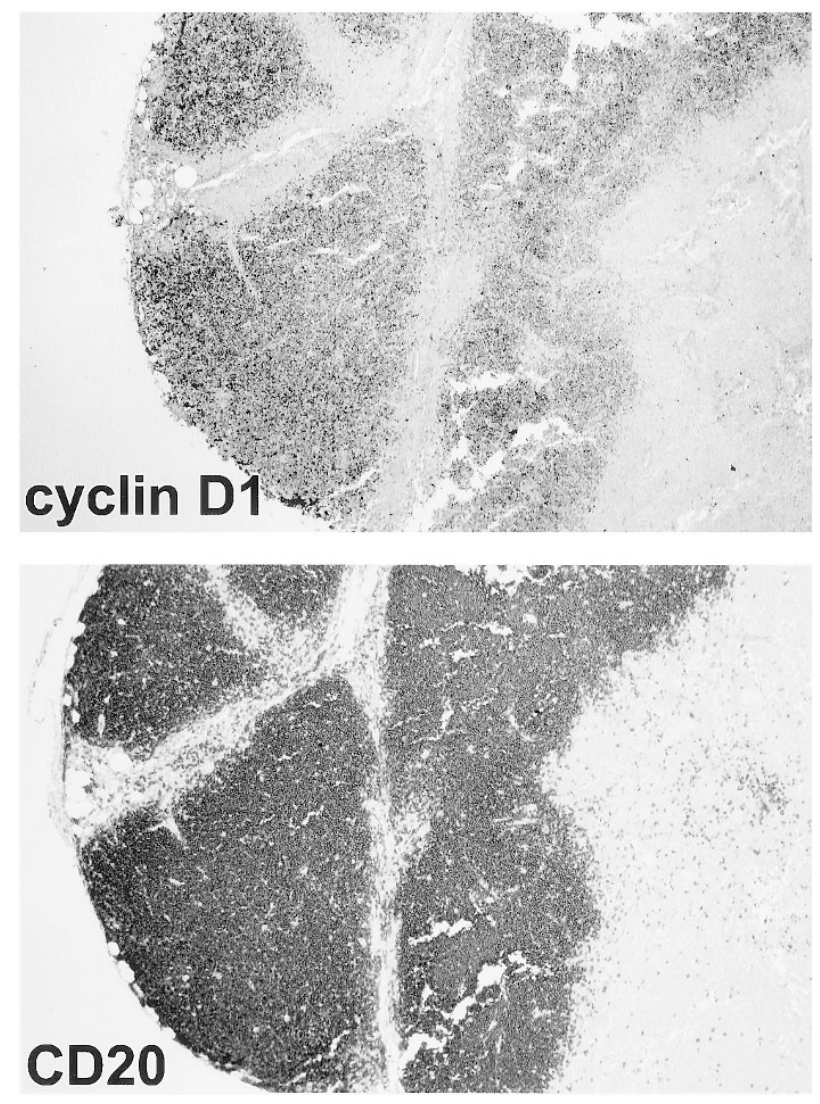

FIGURE 4. Mantle cell lymphoma partially infiltrating a lymph node in Case 2. Cyclin D1 and CD20 immunostains label neoplastic cells, which involve the left two thirds of the node, whereas the right third is not affected (original magnification, 40×).

Immunohistochemistry and Molecular Studies

Immunohistochemically, the atypical lymphocytes in both cases were reactive for CD20 and CD5 (Fig. 5), whereas CD3, CD10, and CD23 were unde- tectable in the abnormal cells. Cyclin D1 was clearly demonstrated in the atypical nuclei (Fig. 5), and Ki-67 stain showed a labeling consistent with low proliferative activity of the lymphoma cells in the colon and slightly higher activity in the lymph nodes of Case 2.

PCR analysis performed on the paraffinembedded tissue from the ileum lesion in Case 1 and from the involved lymph nodes in Case 2 revealed both clonal immunoglobulin heavy-chain and bcl-1 gene rearrangements (Fig. 6). A summary of the main immunohistochemical and molecular analysis findings is presented in Table 2.

\section{DISCUSSION}

The coexistence of primary colonic lymphoma and adenocarcinoma is an extremely uncommon event. To the best of our knowledge, only three case reports have been previously published (3-5). In one case, the subtype of lymphoma was reported to be a "large-cell, histiocytic" type, which developed in a 14-year-old boy with IgA deficiency (3). The second case was reported as a non-Hodgkin's lymphoma of the diffuse small-cell type, with plasmacytoid features (5). The third case was a large mass in the terminal ileum reported as "follicular lymphoma of medium-sized cell type" (4). In all these cases, the cytologic or architectural features were different from those of mantle cell lymphoma. Thus, it would appear that our cases constitute the first report of coexistent colonic mantle cell lymphoma and invasive adenocarcinoma. The diagnosis of mantle cell lymphoma was confirmed by the detection of B-cell clonality, the characteristic coexpression of CD5 and CD20, the expression of cyclin D-1, and the detection of a translocated bcl-1 gene (6).

The terms multiple lymphomatous polyposis was introduced in 1961 by Cornes to describe malignant lymphoma that presented as multiple polyposis affecting long segment of the gastrointestinal tract (14). In the original description, multiple lymphomatous polyposis was a heterogenous entity that included both Hodgkin's and non-Hodgkin's lymphoma. Since then, other forms of gastrointestinal lymphoid processes, such as immunoproliferative small-intestinal disease, enteropathy-associated T-cell lymphoma, and nodular lymphoid hyperplasia, have been described (15-17). More recent reports of multiple lymphomatoid polyposis describe a less heterogeneous disorder, mostly representing mantle cell lymphoma (8-11, 18-20).

The characteristic clinicopathological features of lymphomatous polyposis are as follows: a male predominance, relatively old age ( $>50$ years old), and a strong tendency of dissemination throughout the 
TABLE 1. Clinicopathologic Features of "Early" Mantle Cell Lymphoma

\begin{tabular}{|c|c|c|c|c|c|c|c|c|}
\hline Case & Site & $\begin{array}{c}\text { Gross } \\
\text { Appearance }\end{array}$ & Distribution & Depth & $\begin{array}{c}\text { Regional } \\
\text { Lymph Nodes }\end{array}$ & Bone Marrow & $\begin{array}{l}\text { Distant } \\
\text { Lymph } \\
\text { Nodes }\end{array}$ & Spleen \\
\hline 1 & $\begin{array}{l}\text { Terminal } \\
\text { ileum }\end{array}$ & polypoid & single polyp & submucosa & uninvolved & uninvolved & $\begin{array}{l}\text { clinically and } \\
\text { radiologically } \\
\text { uninvolved }\end{array}$ & $\begin{array}{l}\text { clinically and } \\
\text { radiologically } \\
\text { uninvolved }\end{array}$ \\
\hline 2 & Sigmoid & $\begin{array}{l}\text { normal } \\
\text { mucosa }\end{array}$ & $\begin{array}{l}\text { multiple small } \\
\text { nodules }\end{array}$ & submucosa & Involved & $\begin{array}{l}\text { minimally involved } \\
\text { by flow } \\
\text { cytometry }\end{array}$ & $\begin{array}{l}\text { clinically and } \\
\text { radiologically } \\
\text { uninvolved }\end{array}$ & $\begin{array}{l}\text { clinically and } \\
\text { radiologically } \\
\text { uninvolved }\end{array}$ \\
\hline
\end{tabular}

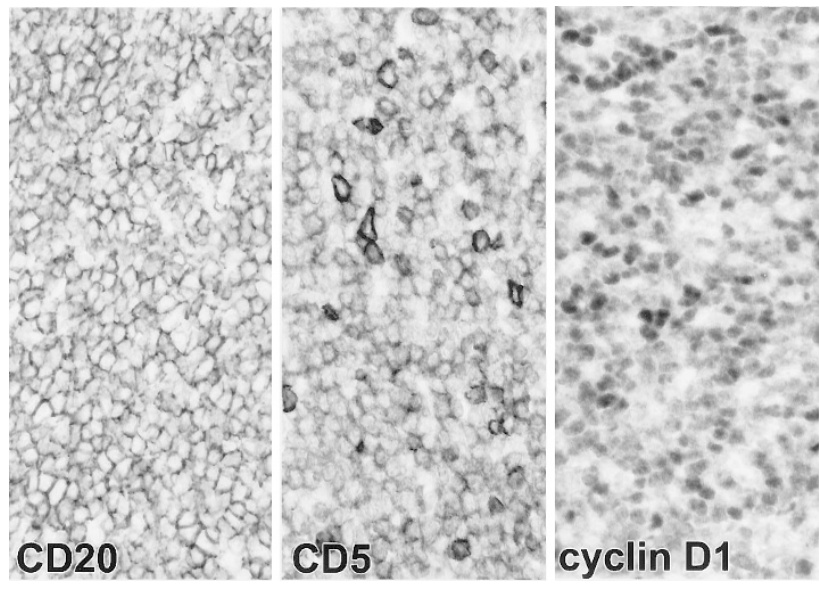

FIGURE 5. Immunohistochemical stains of Case 2. Lymphoma cells shows strong reactivity to CD20 and are dimly positive for CD5. A few reactive $\mathrm{T}$ cells, showing strong positivity to CD5, are also identified. Cyclin D1 is clearly observed in the nuclei (original magnification, $600 \times)$.

gastrointestinal tract $(9,10,18,21)$. Moreover, at diagnosis, the involvement of lymph nodes and distant organs, bone marrow, liver, and Waldeyer's ring is frequent $(9,10,18,21)$. About half of the cases of lymphomatoid polyposis reported had an intestinal mass, mainly at the ileocecal region, which may be the primary site of the disease (11). However, some cases of mantle cell lymphoma exhibit lymphomatous polyposis without a distinct mass lesion in the gastrointestinal tract $(9,10,18)$.

The most salient feature of our cases was the absence of multiple polyposis and/or multifocal gastrointestinal involvement. Instead, in one case, there was a single polypoid mass without disseminated involvement or regional lymph node involvement. In the other case, the mucosa was grossly unremarkable, but there were multiple microscopic foci of lymphomatous infiltrate and partial regional lymph node involvement. In the second case, the colonic mucosa was also considered to be the most likely site of origin despite evidence of multifocality. Arguments supporting this interpretation were that most of the neoplastic load was located in the intestinal mucosa, with only small positive nodes $(\leq 0.3 \mathrm{~cm})$ and few circulating cells in the bone marrow detected only by flow cytometric analysis.

In both cases, the lymphoma was diagnosed incidentally. In both instances, the invasion of the metastasizing adenocarcinoma was deeper than that of lymphoma, indicating advanced disease and most likely responsible for the rectal bleeding. We also contend that because the two cases show neither the characteristic appearance of classical multiple polyposis nor a dominant mass and, if any, minimal extraintestinal involvement, they most likely represent early phases of intestinal mantle cell lymphoma.

Our findings suggest that early intestinal mantle cell lymphoma may present in at least two different ways. The first type of progression would begin as a single lesion that represents the primary focus of the disease. Dissemination throughout the intestinal tract would then develop only after the solitary lesion reaches a large mass. The second type would demonstrate disseminated multiple mucosal involvement in its early phase, forming nodules that may gradually enlarge to eventually produce typical multiple polyps. Interestingly, in both of our cases, the proliferative activity detected by Ki- 67 antibody was rather low, which may be a characteristic of early-phase mantle cell lymphoma. Although it appears that mantle cell lymphomas with low proliferative rates follow a more prolonged clinical course than those with faster growth kinetics, the outcome of patients with these tumors is generally poor (13).

Intestinal mantle cell lymphoma has been reported to have a strong tendency to involve extraintestinal organs at its presentation $(9,10,18$, 21). However, these reports were based on observations of cases with fully developed multiple polyposis. Therefore, it has not been clear at which phase of the disease the dissemination occurs. In Case 2, minimal involvement of bone marrow and regional lymph nodes was identified even before the intestinal lesion was clinically evident. These findings suggest that intestinal mantle cell lymphoma may disseminate at its early phases, contrasting with intestinal marginal zone B-cell lymphoma, which, because of the "homing" effect, is essentially localized to the intestinal tract at the time of diagnosis and is slow to disseminate, especially to the bone marrow (22).

In summary, we report two cases of concurrent primary intestinal mantle cell lymphoma and co- 


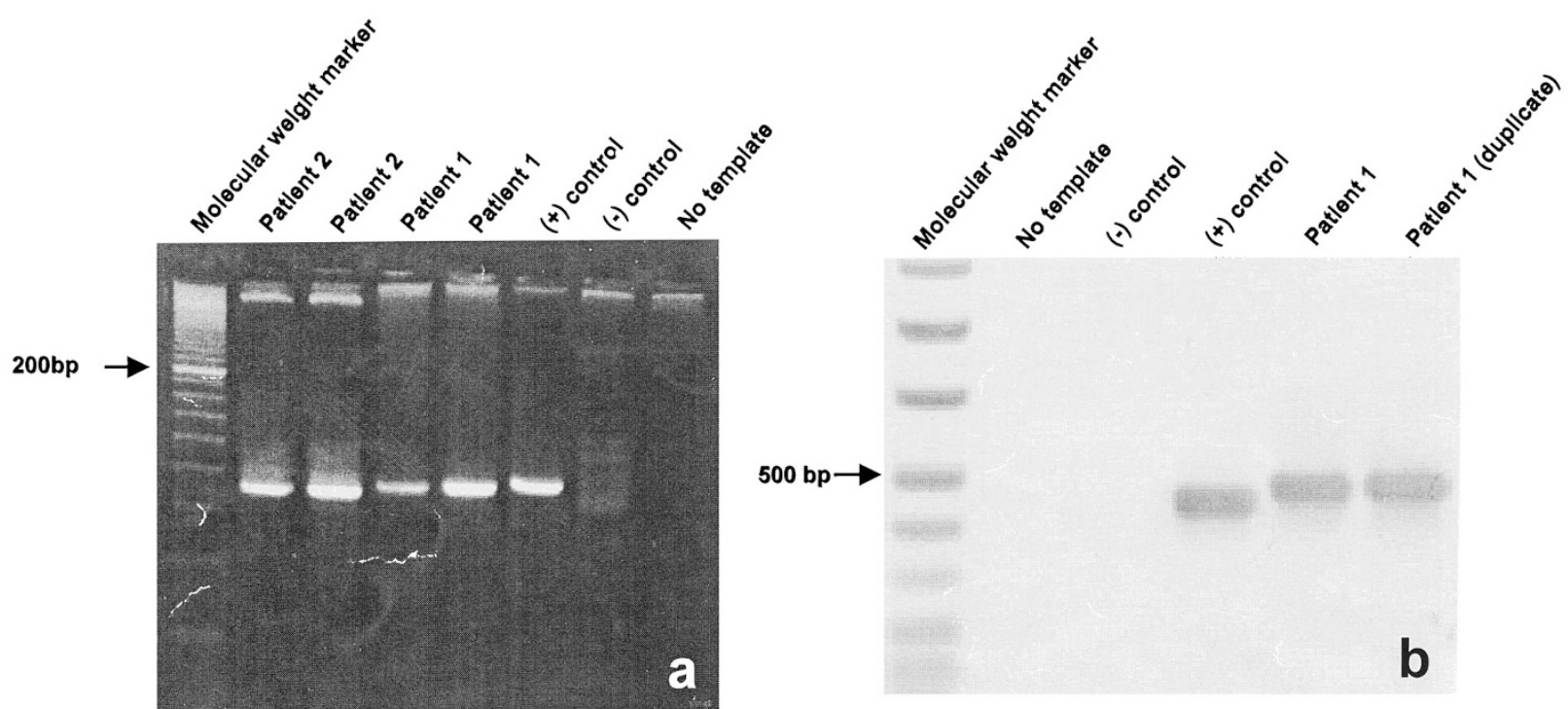

FIGURE 6. (A) PCR analysis of immunoglobulin heavy-chain rearrangement using $J_{H}$ and $V_{H}$ consensus primers. The ethidium bromide-stained gel demonstrates single distinct bands ranging from $80-100 \mathrm{bp}$, consistent with the presence of monoclonal B-cell populations in both patients' lymphoma samples. (B) PCR analysis of bcl-1 gene rearrangement in the lymphoma from Case 1. A band of approximately 500 bp corresponding to the $t(11 ; 14)$ is observed.

TABLE 2. Immunohistochemical and Molecular Genetic Studies

\begin{tabular}{clccccccccc}
\hline Case & Tissue & CD20 & CD3 & CD5 & Cyclin D1 & CD10 & CD23 & $\begin{array}{c}\text { Percentage of } \\
\text { Ki-67(+) } \\
\text { Cells }\end{array}$ & $\begin{array}{c}\text { Bcl-1 } \\
\text { Translocation }\end{array}$ & Clonal VJ \\
\hline 1 & Ileum & + & - & + & + & - & - & 8 & + & + \\
2 & Colon & + & - & + & + & $\mathrm{ND}^{b}$ & $\mathrm{ND}$ & 5 & $\mathrm{ND}$ & + \\
2 & Lymph node & + & - & + & + & - & - & 11 & + & + \\
\hline
\end{tabular}

VJ, immunoglobulin heavy-chain gene rearrangement; ND, not done.

lonic adenocarcinoma. The association of carcinoma and mantle cell lymphoma in these patients was very likely fortuitous. Most interestingly, mantle cell lymphomas, which are usually more advanced and disseminated at diagnosis, were unexpectedly found in what appeared to be early stages of development. Thus, these two cases offered a unique opportunity to identify the initial phases of mantle cell lymphoma and speculate about their progression in the intestine.

Acknowledgments: The authors thank Elaine O. Dooley, B.S., HTL (ASCP), and Kim P. Ahrens, B.S., for technical assistance.

\section{REFERENCES}

1. Devesa SS, Blot WJ, Stone BJ, Miller BA, Tarone RE, Fraumeni JF Jr. Recent cancer trends in the United States. J Natl Cancer Inst 1995;87:175-82.

2. Devesa SS, Fears T. Non-Hodgkin's lymphoma time trends: United States and international data. Cancer Res 1992;52(19 Suppl):5432s-40s.

3. Mir-Madjlessi SH, Vafai M, Khademi J, Kamalian N. Coexisting primary malignant lymphoma and adenocarcinoma of the large intestine in an IgA-deficient boy. Dis Colon Rectum $1984 ; 27: 822-4$.
4. Sugihara S, Yamaguchi A, Matsumura K, Fujimura H. Concurrent malignant lymphoma of the jejunum and multiple synchronous colon cancers. Am J Gastroenterol 1983;78: 341-5.

5. Wagle SD, Mohandas KM, Vazifdar KF, Dhir V, Swaroop VS, Jagannath $\mathrm{P}$, et al. Synchronous adenocarcinoma and lymphoma of the colon. Indian J Gastroenterol 1997;16:28-9.

6. Banks PM, Chan J, Cleary ML, Delsol G, Wolf-Peeters C, Gatter K, et al. Mantle cell lymphoma. A proposal for unification of morphologic, immunologic, and molecular data. Am J Surg Pathol 1992;16:637-40.

7. Luthra R, Hai S, Pugh WC. Polymerase chain reaction detection of the $t(11 ; 14)$ translocation involving the bcl-1 major translocation cluster in mantle cell lymphoma. Diagn Mol Pathol 1995;4:4-7.

8. Isaacson PG, MacLennan KA, Subbuswamy SG. Multiple lymphomatous polyposis of the gastrointestinal tract. Histopathology 1984;8:641-56.

9. O'Briain DS, Kennedy MJ, Daly PA, O'Brien AA, Tanner WA, Rogers $\mathrm{P}$, et al. Multiple lymphomatous polyposis of the gastrointestinal tract. A clinicopathologically distinctive form of non-Hodgkin's lymphoma of B-cell centrocytic type. Am J Surg Pathol 1989;13:691-9.

10. Ruskone-Fourmestraux A, Delmer A, Lavergne A, Molina T, Brousse N, Audouin J, Rambaud JC. Multiple lymphomatous polyposis of the gastrointestinal tract: prospective clinicopathologic study of 31 cases. Groupe D'etude Lymphomes Digestifs Gastroenterol 1997;112:7-16.

11. Lavergne A, Brouland JP, Launay E, Nemeth J, RuskoneFourmestraux A, Galian A. Multiple lymphomatous polypo- 
sis of the gastrointestinal tract. An extensive histopathologic and immunohistochemical study of 12 cases. Cancer 1994; 74:3042-50.

12. Trainor KJ, Brisco MJ, Wan JH, Neoh S, Grist S, Morley AA. Gene rearrangement in B- and T-lymphoproliferative disease detected by the polymerase chain reaction. Blood 1991; 78:192-6.

13. Segal GH, Masih AS, Fox AC, Jorgensen T, Scott M, Braylan RC. CD5-expressing B-cell non-Hodgkin's lymphomas with bcl-1 gene rearrangement have a relatively homogeneous immunophenotype and are associated with an overall poor prognosis. Blood 1995;85:1570-9.

14. Cornes J. Multiple lymphomatous polyposis of the gastrointestinal tract. Cancer 1961;14:249-57.

15. Isaacson PG, Dogan A, Price SK, Spencer J. Immunoproliferative small-intestinal disease. An immunohistochemical study. Am J Surg Pathol 1989;13:1023-33.

16. O'Farrelly C, Feighery C, O'Briain DS, Stevens F, Connolly $\mathrm{CE}, \mathrm{McC}$ arthy $\mathrm{C}$, et al. Humoral response to wheat protein in patients with coeliac disease and enteropathy associated T cell lymphoma. Br Med J (Clin Res Ed) 1986;293:908-10.
17. Ranchod M, Lewin KJ, Dorfman RF. Lymphoid hyperplasia of the gastrointestinal tract. A study of 26 cases and review of the literature. Am J Surg Pathol 1978;2:383400 .

18. Moynihan MJ, Bast MA, Chan WC, Delabie J, Wickert RS, Wu $\mathrm{G}$, et al. Lymphomatous polyposis. A neoplasm of either follicular mantle or germinal center cell origin. Am J Surg Pathol 1996;20:442-52.

19. Shepherd NA, Hall PA, Coates PJ, Levison DA. Primary malignant lymphoma of the colon and rectum. A histopathological and immunohistochemical analysis of 45 cases with clinicopathological correlations. Histopathology 1988;12:235-52.

20. Triozzi PL, Borowitz MJ, Gockerman JP. Gastrointestinal involvement and multiple lymphomatous polyposis in mantlezone lymphoma. J Clin Oncol 1986;4:866-73.

21. Isaacson PG. Gastrointestinal lymphoma. Hum Pathol 1994; 25:1020-9.

22. Cogliatti SB, Schmid U, Schumacher U, Eckert F, Hansmann ML, Hedderich J, et al. Primary B-cell gastric lymphoma: a clinicopathological study of 145 patients. Gastroenterology 1991;101:1159-70. 